JELTL (Journal of English Language Teaching and Linguistics) e-ISSN: 2502-6062, p-ISSN: 2503-1848

2019, Vol. 4(1)

www.jeltl.org

\title{
Style Translation in an English Version of Tunisian Mustapha Tlili's novel The Lion Mountain: A Cognitive Basis to Assessment
}

\author{
Khalid Majhad \\ Hassan II Mohammedia-Casablanca University, Morocco \\ e-mail:kh.majhad@gmail.com \\ Chakib Bnini \\ Hassan II Mohammedia-Casablanca University, Morocco \\ Mohammed Kandoussi \\ Hassan II Mohammedia-Casablanca University, Morocco
}

\begin{abstract}
Style is every literary author's identity marker. No translation can ever claim success if it does not reflect the marked stylistic features of the original. This paper assesses the English translation of Tunisian Mustapha Tlili's novel Lion Mountain in terms of its reproduction of the spirit of the source text, that is the totality of effects generated by the author's stylistic manners. A cognitive basis to assessment means that the author's style is a direct expression of his state of mind, his attitudes and beliefs. This model, inspired by the work of Chinese translator and theorist Jin Di (2003), uses a hermeneutic four-stage analysis of literary texts (i.e. penetration, acquisition, transition and presentation), that makes it possible to deal in a rather systematic manner with every aspect of the literary text, namely its spirit, substance, overtone, flavor and imagery. The assessment will demonstrate how translating successes or failures result directly from successes or failures in applying one or more of these hermeneutics-inspired four stages.
\end{abstract} Keywords: Literary translation quality assessment, cognitive stylistics, Maghrebian Francophone literature, Mustapha Tlili 


\section{INTRODUCTION}

Translation is the only way literature can travel into new receiving cultures, and this places a heavy responsibility on the translator whose job is expected to invite world readers into the cultural realms of one another. Literary translation, as we have argued so far, is not at all about transmitting facts from a novel or a poem but a window into other authors' artistic ways of seeing and analyzing certain human experiences. The endeavor invested in this paper is intended, as it were, to 'publicize' francophone Maghrebi literature and promote quality translation of it. Having a sense of what a good translation is requires that we review previous pitfalls in the existing translations and praise successful practices. A translator needs a guiding theory, a comprehensive and holistic one such as this we are elaborating based on the works of Jin Di and Boase Beier. The importance of Di's artistic theory is obvious enough in that it only describes good practice, but does not dictate it. Also, it seems to help 'alert the literary translator to phenomena he may not otherwise notice, especially to subtle aspects of the style of the source text' (Beier, 2010, p. 111).

Style is by far a key component in the making up of a literary work and a basic criterion for quality assessment since it is the element that captures the 'spirit' and literariness. Faithful style reproduction in the target text is viewed as the principal indicator of translational artistic integrity. Ignoring it is a form of injustice and a sign of sloppiness in dealing with lesser known and minor literatures. Whatever way we look at it, style remains every author's distinctive manner of using language and achieving literariness. Authors build literary recognition on a strict sense of individualism. While national literatures are increasingly 'going global' thanks to translation, authors would expect that translators show and 'reproduce their individual visions and unique points of view in other languages too (Parks, 2007, p.239).

Parks also insists that 'style is absolute, you take it or leave it, and if it is lost in translation, then, the author and their individual vision are lost too' (p.241). In a similar vein, Wales (1989) warns that translators should not 'regard style decoratively' but look at it as 'some kind of expressive emphasis 'added' to an utterance'. (p.399). This paper assesses the English translation of Tunisian Mustapha Tlili's novel Lion Mountain in terms of its reproduction of the spirit of the source text, that is the totality of effects generated by the author's stylistic manners.

\section{LITERATURE REVIEW}

\subsection{Matters of style and Methodological issues in literary translation quality assessment}

\subsubsection{What is 'Style': General views and definitional attempts}

Style is a defining aspect of every text, every author, every genre, and perhaps every epoch. In a broader sense, it is the specific 'way in which language is used in a given context, by a given person, for a given purpose, and so on' (Leech \& Short, 2007, p. 26). In technical terms, referring back to the Saussaurian structuralist framework, style belongs to the domain of 'parole', being a choice among the variation allowed by the 'langue' system when conveying a specific meaning (Herrmann, Dalen-Oskam \& Schöch, 2015, p. 39).

For us as style analysts, this definition does not seem to be helping our understanding of the notion of style. Hardly anything is said about what features constitue a given style, how to 
arrive at them, and what sort of conclusions can be made out of them. These are actually the same questions that still pose a difficulty in delimiting the scope of stylistics. Throughout all the developments in the study of syle, two major appoaches have been at work: One that is linguistic in essence, quantitative, stylometric (statistics-based), attributional, and descriptive, and another that is qualitative, interpretative, and intuitive. Applied to literary writing, the first approach aims to identify 'the linguistic habits of a particular writer ('the style of Dickens, of Proust', etc.), and at other times it has been applied to the way language is used in a particular genre, period, school of writing, etc' so a unity among certain corpora of texts could eventually be established (Leech \& Short, 2007, p. 26). It is as such a means of 'authorship detection', trying to identify features of text which remain constant whatever the artistic or other motives of the writer'(p. 28). Contrariwise, the second approach views style as a 'relational concept', considering chosen stylistic features to be related to and motivated by artistic and attitudinal factors. This view is largely based on 'an assumed dualism, in language, between form and meaning' (p. 30). In practice, however, the two approaches most often function in combination rather than in separate spheres.

Along the way, definitions of style have constanly been revised and expanded as the field of stylistics has worked its way into newer realms of literary, discourse and translation studies. One particular definition of style with respect to literary writing is that it is a purposeful " individual, original, deviation from normal language usage [ ...] to express an emotion' (Herrmann, Dalen-Oskam \& Schöch, 2015, p. 34), and simultaneously generate an aesthetic effect.

Ghazala (2018) also noted the use of the term in the evolving stylistics literature as being the 'genius' and 'spirit' of the literary text, and a reflection of the author's mind (p. 15). This view that style contains the essence of a text's spirit indicates an appreciation of the 'totality of stylistic characteristics of the way in which an author expresses himself in language, be it prose or verse (Herrmann, Dalen-Oskam \& Schöch, 2015, p. 35). Features of a given style may stand out at such a wide range of levels as 'the choice of words, the use of tropes, sentence structure and composition, structure, tone of voice, connotation/association, narrative technique, etc' $\mathrm{p}$. $37)$.

At the other extreme, Jenny (1993) argues that literary style is a 'singularite'. This means that stylistics is concerned 'precisely with phenomena that eschew any attempt to categorize, class and analyze them, because style's absolute uniqueness makes it irreducible to any category or class, and stylistic phenomena cannot be grouped and compared to each other or to similar phenomena in other texts' (as cited in Herrmann, Dalen-Oskam \& Schöch, 2015, p. 41).

Methodologically, style markers can generally be observed both quantitatively or qualitatively. An integrated approach deploying both would lead to more evidence-based interpretations, whereby computed frequency is related to significance (p. 44). Interestingly, Jannidis (2014) views such stylistic readings as 'hermeneutic acts of sense making' (as cited in Herrmann, Dalen-Oskam \& Schöch, 2015, p. 47).

\subsubsection{Style in literary translation}

Whatever way we look at it, style remains every author's distinctive manner of using language and achieving literariness. Authors build literary recognition on a strict sense of 


\section{Khalid Majhad, Chakib Bnini \& Mohammed Kandoussi}

individualism. Parks (2007) equates every style with a certain vision of reality, one which 'subverts the conventional language and the common view of things' (p.241). While national literatures are increasingly 'going global' thanks to translation, authors would expect that translators show and 'reproduce their individual visions and unique points of view in other languages too (Parks, 2007, p.239). Parks also insists that 'style is absolute, you take it or leave it, and if it is lost in translation, then, the author and their individual vision are lost too' (p.241). He cites the attitudes of writer Milan Kundera about the 'supreme authority' of the author and how 'he wishes to be truly Kundera in whatever part of the globe his books appear, Kundera in French, Kundera in English, Kundera in Italian, Kundera in Russian, Kundera in Chinese. He is looking for the supreme confirmation of his individuality, unlimited by cultural or linguistic context' (p.241).

More than that, style, following BoaseBeier (2006), is indicative of a source author's 'cultural space-time'. She gives the example of Dante's style in Divina commedia, which 'signals that it was written by a medieval Tuscan' (cited in Jones, 2008, p.153). Generally, as Munday (2008) argues, style is a set of 'linguistic habits' that can be specific to an individual, to a genre or to a period.

In a similar vein, Wales (1989) warns that translators should not 'regard style decoratively' but look at it as 'some kind of expressive emphasis 'added' to an utterance'. She adds that 'all utterances have a style, even if they might seem relatively 'plain' or unmarked: a plain style is itself a style' (p.399). Miko (1970) went so far as to insist that the translator 'has no other goal but the preservation of the expressive character, which is the style, of the original' (as cited in Munday, 2008, p.29). Contrariwise, a rather flexible stance is upheld by relevance theory scholars (e.g. Levy, 1967; Gutt, 1991) who apply a Minimax principle to translation. This principle means that translation, as a decision making process, involves weighing right options among many, or in plainer terms, options which 'yield maximum effect for minimum effort' (as cited in Hatim \& Munday, 2004, p. 56). The central question these theorists ask is whether the effort invested in preserving a given feature (e.g. rhyme) would be of any use to the target reader in retrieving 'a meaning, a nuance, an implication, a subtle hint, etc.'. If, for example, 'a rhyme turns out not to be essentially meaningful in the target context (not 'relevant'), the translation would have gratuitously upset the interaction of stimulus (in this case the rhyme), contextual assumptions and interpretation' (Hatim \& Munday, 2004, p. 60). This view has a functionalist dimension in a sense that any instance of textual 'salience' needs to be 'communicatively motivated' and serving a particular rhetorical purposes if it is to be worth preserving in the target text' (p.60).

In technical terms, the specificity of a given style is realized at levels of 'formal and lexical features'. Formal features, according to Munday (2008), consist in 'discourse markers, sentence structure, clause order, and parallelism, while lexical features include the frequency and familiarity of words, combinations of words, archaisms or modern usage' (p.29).

\subsubsection{Literariness and the making of the novel}

Though not readily defined, literariness is a property ascribed to any literary work ranging from prose, poetry to drama. A core criterion for literariness is the meaningful deviation from language usage norms. Following Wales (1989), literariness is an aesthetic value or effect of 
texts admired for their formal 'beauty' arising from structural patterning or expressive and connotative qualities which override a simple informative function (p.234).

Through purposeful uses of artistic devices such as foregrounding and metaphoricity, a literary work creates newer and stronger meanings. However, as Geniené (2003) points out, literariness cannot be reduced simply to aesthetic appeal. She insists that literary analysis and appreciation have to be about understanding the various cognitive operations underlying the deployment of literary devices, hence the cognitive turn in recent models of literary translation such as Jin Di's Artistic Integrity theory, which purports to be a holistic approach that attends to every aspect of the artistic make-up of a literary work. In dealing with the related issues of meaning interpretation and style reproduction, the theory makes use of Steiner's Hermeneutic motion but with a renaming of the four stages. It first of all draws a strict line between guesswork and real hermeneutic analysis. The moves are thus re-elaborated as follows:

a. Penetration (into what): As its name suggests, penetration means that a translator has to 'enter the linguistic and cultural environment of the source text'. One way he could do that is by 'operating with source-language concepts and by thinking in that language. This stage requires that the translator 'consciously bars the interference of his own language, and that he develops a 'sensitivity' to the words, their structures and associated concepts' ( $\mathrm{p} 55$ ). In other words, penetration is an exhaustive study of 'the whatness of things and feelings'. Interpretation without penetration remains only a matter of facile, ineffective, and often misleading, guesswork' (p. 67).

b. Acquisition (of what) : This move is about fully comprehending the various aspects of the 'message', that is its spirit, substance and flavor' (p54).

c. Transition (from what to what): Once the message has been acquired, the translator begins an 'empathetic re-creation: creating new imagery that may carry the closest possible message in the new environment' (p.84). This involves finding 'natural ways' of expression with which native speakers communicate with each other' (p85). Di asserts that a key to the success in the transition move is 'freeing oneself from the interference of the foreign language' (p85). However, the translator is supposed to 'be jealous of the form of the original which, according to Gombrish (1981), 'modifies, refines and articulates thought' (cited in Di, 2003, p85). Di later retorts that the thing to be jealous of is not actually the 'form of the original in itself but the effect that form produces on the reader' [...] as rigid adherence to the original form without proper formal adjustments may not produce the desired effect and therefore distort the thought' $(\mathrm{p} 85)$. Transition is mainly concerned with the 'genius', naturalness, of the target language.

\subsection{Cognitive (interpretative) Stylistics-oriented translation assessment}

Cognitive stylistics, subsuming other subtypes, namely affective and interpretative stylistics, sees meaning as a product of the text [itself] and the human cognitive conceptualization of it based on a certain background knowledge (Nørgaard, Montoro \& Busse, 2015, P.5). This means that texts offer 'communicative clues' or 'clues to intention' that readers associate with 'intended or interpreted meanings'. These clues 'lie in style' (Boase-Beier, 2010, p.40). As a substitute to 'impressionistic' literary criticism, cognitive stylistics 'fuses cognitive science, linguistics and literary studies' in the analysis of literature (Nørgaard, Montoro \& Busse, 2015, P.5). 


\section{Khalid Majhad, Chakib Bnini \& Mohammed Kandoussi}

Style is the clearest expression of the 'author's 'mental state' under certain social and cultural influences (Boase-Beier, 2010). In the previous survey of the francophone Maghrebi novel, it was apparent how the social and political concerns of the Maghrebi authors were mirrored in their styles, a preview of which is noticed in the allegories of chosen titles and ubiquitous ironies. I remind of the highly symbolic short story by Algerian Kabyle writer Mouloud Mammeri, entitled Le Zèbre/ Zebra. At the level of lexical choice, the protagonist's nickname Zebra fully describes the state of identitarian confusion in a society 'torn between tradition and modernity, between past and present, between oral and written traditions, between religion and democracy '(Boudraa \& García, 2014, p.93).

Cognitive stylistics helps translation practice by raising awareness about the importance of prioritizing source stylistic elements, since, far from arbitrary, they are either 'influenced by a certain ideology, take a particular attitude or embody a particular feeling' (Boase-Beier, 2010, p. 80). Faithfulness to style is a necessary 'foreignizing' principle which not only contributes to the preservation of the 'genius' and 'spirit' of the original text but also metaphorically allows a 'meeting of minds' through 'acquainting new readers with thoughts or feelings they have not experienced before' (p.78). Elements of literary style requiring attention may include but not limited to: Ambiguity and textual gaps, foregrounding, salience and visibility, metaphor, deviancy, iconicity and figurative language, etc. These will become clearer during the analysis.

By way of conclusion, I reiterate Boase-Beier's claim that 'translation which is stylistically aware can make a more reasonable case for its interpretation of the source text than any other sort of translation can. It must do this in full knowledge that the translator's interpretation is only one among many (p.110). Of course, there exist other customized stylistics-based assessment models that might opt for different criteria of assessment (e.g. error analysis), and all can, according to Waddington (2001), 'possess criterion-related validity' provided they are 'carefully designed, tested, and applied' (as cited in Saldanha \& O'Brien, 2013, p. 98).

\section{RESEARCH METHODS}

The assessment following the artistic integrity model considers that instances of weak translations are indicative of some mishandling of one or more of the four 'moves' proposed by the model. A typology of mistranslations will be established alongside their potential root causes with regard to requirements of the four moves. For example, translators who are not familiar with the historical and cultural specificities of the Maghreb and who do not attempt a full penetration into this milieu will likely fail to understand the bilingualism and even multilingualism characterizing the writing style of many Maghrebi authors. The end product might eventually be a failed 'standardized' version that misses the point about the distinctiveness of Maghrebian literature. Similarly, if in certain cases ambiguity is an intended idea of an author, then a translator needs to be well informed about its non-gratuitous presence.

Most critical work done on the stylistics of francophone Maghebi novel has dealt with it in its original language while only very little on its appearance in translation. Those preexisting critical studies, mostly in French, will be revisited and supplemented with personal close readings for insights about the literary and stylistic characteristics of the source and target versions of the novels under analysis. A qualitatively valid stylistic analysis is one that is 
supported by ample 'contextualizaton' by means of a detailed account of the social, political and cultural influences surrounding the literary work. The next section study opens with a biobibliographical account on the author as a basis for his well-supported stylistic analysis. 'Comprehensiveness', on the other hand, means that not even the slightest should remain unaccounted for. .

One related study (Toler, 2001) raises several cogent questions about the way francophone Maghrebi authors are received in the west. Toler denounces the paradoxical fact that Maghrebi author Kateb Yacine, who is a multilingual world traveller, is 'always presented as essentially Algerian and Arab', whereas Western T.S. Eliot is presented as being 'cosmopolitan'. Even worse is that many translators and/or publishers of Maghrebi novels present their translated works not as works of art, but as ethnographic glimpses into the mind and culture of the 'Other'. Toler attests:

As such, many (perhaps even most) published translations indicate that the translators have taken considerable liberty with the source texts, failing to devote adequate attention to, or even purging, the original of many of its most important literary and stylistic merits. Often this neglect has implications that reach far beyond simple aesthetic considerations. (p. 50)

Toler's assessment was concerned with the rendition of the general 'hyprid' character intrinsic to the plurilingual and pluricultural make-up of the Maghrebi novel. He sees that many English translations erroneously standardized the source text. Francophone authors' indigenized mode of writing is a mark of 'resistance to appropriation into standard French', that 'must not be appropriated into English, either' (p. 62).

\section{RESULTS}

\subsection{Assessmemnt of the English Translation of La Montagne du lion by Tunisian Mustapha Tlili}

\subsubsection{Author profile}

Unlike most Maghrebian authors, Tunisian novelist Mustapha Tlili's creative talent is the least talked about but one that is in fact found stunning upon reading. Having led a life moving between Paris and New York for educational and professional reasons, Tlili does emanate imprints of a nomadic exile experience throughout the whole of his oeuvre. Tlili's four novels are an embodiment of 'l'auto-représentation de l'écriture', in which every 'personnage est à lire comme une métaphore de la condition de Mustapha Tlili, [...] se délivrant de ses angoisses' [every character is a metaphor of the condition of Tlili himself] (Gontard, 1996, para. 25).

Tlili's heroes are unique in their absolute solitude and isolation from their origins, just as he himself is. Gontard (1996) concludes that 'avec Mustapha Tlili quelque chose change fondamentalement dans la mesure où le personnage romanesque (narrateur ou acteur) se trouve totalement coupé de ses origines et isolé dans un double éloignement, au sein d'une culture autre, où il n'a même plus pour lui la présence de la famille ou du groupe qui apparaît dans les récits de l'émigration' [What is unique about Tlili's characters is their double alienation; they are foreign with regard to both the home and host cultures] (para.4).

La montagne du lion is significantly a piece of moralist literature, with a sweeping tone of nostalgic longing for one's roots and the authenticity and harmony of the people of the village. Morality here means maintaining loyalty to ancestors by never, at any cost, relinquishing one's material and symbolic heritage. Sticking together with one's people against threats is a default 
option for the dwellers. Horia, the strong mother figure that strives to preserve her ancestors' heritage, persevered in so doing until she eventually 'finit sa vie en beauté' (Déjeux, 1988, p.43), preferring a decent end to her life to allowing any disfigurement of the longstanding features of her village.

In contrast to previously studied francophone Magrebian authors, Tlili's writing in French is strictly conventional but in an engaging style so formidably full of emotion that a reader is forced to reconsider their very humanity. His readers would surely come across characters that remind them of their own conditions and voices their same aspirations.

So far, the assessment of translations has focused on the ways the translators dealt with the marked artistic features of every author (e.g. Djebbarian and Meddebian defamiliarizing writing). In La montagne du lion, most marked is Tlili's abundant use of figures of speech. Revered homeland is made to speak, feel, react to and reciprocate the love its people has for her.

\subsubsection{Notes on the novel}

What Tlili's never-yielding characters eventually want in the face of mounting injustices is 'La mort en beauté' (to die gracefully). The novel is filled with a strong emotional load and reads as a fervent moral stimulus for post-independence generations to maintain links with their roots. It is on the surface a story of an old widow whose life suddenly goes awry because 'l'ordre des seigneurs savants-guerriers n'est plus respecté. Un ordre nouveau, tyrannique, est apparu. Un "Vieux Fou" dirige le pays'. La folie de cette femme folle par tant d'injustices rend Saâd fou à son tour, mais "fou de bonheur". La folie désormais permet de régler les comptes, 'tous les comptes' [...because of a new foolish tyrant stepping in. Injustice drives this old woman and her servants to madness, but madness turns out to give them an extraordinary power to settle scores] (Déjeux, 1988, p. 43).

A further thematic dimension to the novel is its portrayal of the ruined life of expatriate intellectuals, whom everyone expects to possess the ultimate solutions to all sorts of predicaments back at home. The villagers unanimously refer to anyone in this category as 'docteur', possessor of great knowledge acquired oversees. Strongly emphasized in the novel is 'l'impuissance du narrateur à cause de son éloignement' [his impotence due to his insurmountable alienation] (Gontard, 1996, para.10). This remarkably creates a circle of overlapping sentiments among the author, the narrator and the Maghrebian individual alluded to (para.11). It is a whole fictional world of emptiness, injustice and disorder leading eventually to violence. Such is the tragic end of even the two superbly kind humans, 'Horia and her loyal servant Saâd', after reaching a deadlock in their struggle against tyrannical rule. The novel closes with the scene when they open fire on everyone attending the ceremony heralding the conversion of the village into a modernized tourist spot. They nevertheless died in the most beautiful of manners, undefeated and unyielding.

\subsubsection{About the translating body}

Holder of a $\mathrm{PhD}$ in French literature and experienced translator of over sixty works from France and the francophone world, many of which are award winning, and one who affirmed with confidence that she 'would never translate a book unless she could read it with complete understanding' (from interview with . Roberts, 2013, April 8), American Linda Coverdale is 
definitely in a good position to be a reference for what a successful literary translation looks like. Invoking her announced commitment to 'provide the reader with as much of the sense and sensibility of the French original as possible' in every work she accepts to translate, this Artistic Integrity-informed assessment will look into the extent to which the translator managed to relay the full emotional load contained in Tlili's symbolism and abundant figures of speech. Her publisher Three Continents Press (now Lynne Reinner Press) has a long history of publishing literary works from the Maghreb such as Driss Chraibi and Assia Djebar.

\subsection{Four-level assessment of the translation}

\subsubsection{Penetration move assessment}

La montagne du lion poses a different kind of difficulty for translation. Not its complexity but its astonishing simplicity and smoothness are what could ironically have been the challenge. What is called for here besides linguistic and cultural cognizance is a poetc touch that could reproduce Tlili's captivating poeticity and symbolism. The Lion Mountain is the name of the land that is itself a living character in communion with the people of the village.

Symbolism is everywhere in the novel. Starting with the choice of the characters' names, Horia, Saad, Si Sadek, Si Taher, their meanings in Arabic denote in an allegorical manner the noble traits of the characters bearing them. The translator should not miss this point if she is to get into the mood of the novel.

Personification of the village's landmarks and bestowing human qualities on them are an integral aspect to the overall spirit of the text (e.g. le mince ruisseau qui raconte l'époppée des seigneurs... le petit ruisseau qui coule courageusement (p. 97)]. [the brook relates for her the epic of the lords...a little stream flowing bravely (p. 87)].

Similarly, the frequent use of puns and structural parallelism adds up to the poetic flavour to the novel.

The shifts in syntactic structures are largely of the kind attributed to the systemic differences between the two languages, which reflect the genius of each.

\begin{tabular}{|l|l|}
\hline \multicolumn{1}{|c|}{ Original French Text } & \multicolumn{1}{c|}{ English Translation } \\
\hline $\begin{array}{l}\text { Cette terre est leur [les seigneurs], c'est } \\
\text { leur havre, leur lieu de redemption. Ils la } \\
\text { rélcament, elle les rélcame, ils la possèdent } \\
\text { de tout temps [...] désirés par cette terre } \\
\text { qui les appelle et qu'ils appellent. }\end{array}$ & $\begin{array}{l}\text { This land is their land; it is their place of } \\
\text { refuge and redemption. They claim it for their } \\
\text { own, as it claims them in return. It is theirs } \\
\text { and always has been [...].This land desires } \\
\text { them, calls to them, and they answer. }\end{array}$ \\
$\begin{array}{l}\text { Personification, pun and parallelism } \\
\text { La montagne du lion, p.27 }\end{array}$ & \begin{tabular}{l} 
Lion mountain, p.17 \\
\hline
\end{tabular} \\
\hline
\end{tabular}

The translator seems to have tried to maintain the original parallelism, as far as the genius of the target language allows. However, there are cases where the parallelism is compromised.

Assonance, consonance and alliteration are a marked characteristic of Tlili's stylistic consistency. Though no two languages could naturally allow for total resmblance at these prosodic levels, the translator does still have at hand a variety of linguistic options to use for a 
Khalid Majhad, Chakib Bnini \& Mohammed Kandoussi

similar poetic effect. This is something witnessed here with sheer success except for certain cases we may attribute to core systemic differences between French and English. As a general remark, the translator appears to be creatively invisible in the English version, in that the text reads as a new original that only shares the story's substance with the source text.

\begin{tabular}{|l|c|}
\hline \multicolumn{1}{|c|}{ Original French Text } & English Translation \\
\hline $\begin{array}{l}\text { Le village que j'avais quitté m'avait quitté } \\
\text { à son tour. }\end{array}$ & $\begin{array}{l}\text { The village } \text { I had left behind had abandoned } \\
\text { me in turn. }\end{array}$ \\
La montagne du lion, p.84 & $\begin{array}{c}\text { Parallelism slightly compromised } \\
\text { Lion mountain, p.74 }\end{array}$ \\
\hline
\end{tabular}

\begin{tabular}{|c|c|}
\hline Original French Text & English Translation \\
\hline $\begin{array}{l}\text { Nous luttons, chacun lutte. Chacun aussi } \\
\text { dans ce village, c'est ainsi, mon fils- de } \\
\text { tout temps a su ce qui importe et ce qui } \\
\text { importe moins, ce qu'il est possible de } \\
\text { tolérer et ce qu'il ne faut pas tolérer. }\end{array}$ & $\begin{array}{l}\text { We struggle, everyone of us. And everyone in } \\
\text { this village - that's how it is, my son - has } \\
\text { always known what is important and what is } \\
\text { not, what can be tolerated and what cannot. }\end{array}$ \\
\hline La montagne du lion, p.85 & Lion mountain, p.75 \\
\hline $\begin{array}{l}\text { Saad, ta mère, les autres, tout le monde le } \\
\text { sait. Tous, nous savons. Nous tombons, } \\
\text { nous nous relevons. Nous retombons, } \\
\text { nous nous relevons. Il y a des siècles que } \\
\text { cela se passe ainsi, à l'abri de cette } \\
\text { montagne là-bas. }\end{array}$ & $\begin{array}{l}\text { Everybody knows this: Saad, your mother. } \\
\text { All of us, we all know. We fall down, we pick } \\
\text { ourselves up. We fall again, we get up again. } \\
\text { This has been going on for centuries, in the } \\
\text { shelter of the Mountain over there. }\end{array}$ \\
\hline \multicolumn{2}{|l|}{ Emphatic and poetic parallelism } \\
\hline La montagne du lion, p. 85 & Lion mountain, p.76 \\
\hline
\end{tabular}

\begin{tabular}{|c|c|}
\hline Original French Text & English Translation \\
\hline $\begin{array}{l}\text { Et ainsi ceux qui devaient vieillir } \\
\text { vieillissaient, ceux qui devaient mourir } \\
\text { mouraient et la Montagne du Lion } \\
\text { continuait à exister. }\end{array}$ & $\begin{array}{l}\text { And so those who were meant to grow old } \\
\text { grew old, those who were meant to die } \\
\text { passed away, and Lion Mountain endured. }\end{array}$ \\
\hline La montagne du lion, p.123 & Lion mountain, p.114 \\
\hline
\end{tabular}




\subsubsection{Acquisition move assessment}

If the acquisition move means comprehending the various aspects of the 'message', i.e. its spirit, substance and flavor', the translator of this novel, as appears from the following examples, seems to have recogninsed the intended forcefulness of certain key statements in the original and subsequently opted for equally strong turns.

Saad's horrendous torture at the hands of the new tyrants is not easily forgotten. The emphatic stand-alone sentence

\section{- 'Il se souvient'}

is rendred into a negative form in English as

- 'He hasn't forgotten',

with a change in point of view that is refered to in the literature as modulation. Its function is to convey a similar source text idea in a more natural manner in the target language, but without altering its meaning.

One more example of amplifying modulation is witnessed in :

- Les changements qui ont soufflé sur cette partie du monde, translated as,

- The winds of change that swept over this part of the world.

\subsubsection{Transition move assessment}

\begin{tabular}{|l|l|}
\hline \multicolumn{1}{|c|}{ Original French Text } & \multicolumn{1}{c|}{ English Translation } \\
\hline $\begin{array}{l}\text { La décision du vieux Caporal est prise. } \\
\text { Régler un compte, tous les comptes. } \\
\text { Venger une injustice, toutes les injustices à } \\
\text { la fois. }\end{array}$ & $\begin{array}{l}\text { THE OLD Corporal has come to a decision. } \\
\text { Tovenge for an injustice, for all the injustices } \\
\text { at once. }\end{array}$ \\
$\begin{array}{l}\text { Il se souvient. Visage-de-variole. Les } \\
\text { brûlures de cigarettes, les rats, } \\
\text { l'humiliation. }\end{array}$ & $\begin{array}{l}\text { He hasn't forgotten. The Pock-Face. The } \\
\text { cigarette burns, the rats, the humiliation. }\end{array}$ \\
Il se souvient... & $\begin{array}{l}\text { He hasn't forgotten } \\
\text { La montagne du lion, p.167 }\end{array}$ \\
\hline
\end{tabular}

Admittedly, the interest in narrating the story seems to be once again a top priority for the translator, and excessive refomulations of many parts of the texts are clearly visible. One reason for that is to increase the target text's harmony with the geinus of the receptor language. However, most of the shifts are theoretically valid and justifiable. The example just given above can also be invoked here to show the translator's pursuit of naturalness. The English version conveys a much clearer picure for the target reader and spares them any unnecessary ambiguity. 
Khalid Majhad, Chakib Bnini \& Mohammed Kandoussi

\begin{tabular}{|l|l|}
\hline \multicolumn{1}{|c|}{ Original French Text } & \multicolumn{1}{c|}{ English Translation } \\
\hline $\begin{array}{l}\text { Les changements qui ont soufflé sur cette } \\
\text { partie du monde n'ont d'abord que peu } \\
\text { affecté le village. }\end{array}$ & $\begin{array}{l}\text { The winds of change that swept over this part } \\
\text { of the world hardly touched the village a first. }\end{array}$ \\
\hline
\end{tabular}

\begin{tabular}{|l|l|}
\hline \multicolumn{1}{|c|}{ Original French Text } & \multicolumn{1}{c|}{ English Translation } \\
\hline $\begin{array}{l}\text { Chacun de nous est seul face à son visage } \\
\text { intérieur, disait l'Imam. } \\
\text { La montagne } d u \text { lion, p.121 }\end{array}$ & $\begin{array}{l}\text { Each us is alone before our spiritual face, the } \\
\text { imam used to say. } \\
\text { Lion mountain, } \mathrm{p} .112\end{array}$ \\
\hline
\end{tabular}

\subsubsection{Presentation move assessment}

Equivalence in difference is a re-phrase of the translator's ability to reproduce a certain effect by means of more naturally perceived traget language tools. That is the desired translator's creativity in attaining similar poeticity but in accordance with the genius of the target language. This example below shows how the translator asks in her own way the main character's central questions. Both source and target text readers can feel in terms of the genius of their respective languages the emotional load contained in those questions.

- Sais-tu, comment a finit notre mère? Sais-tu jusqu'où l'amour d'une montagne, d'un horison a mené Houria ?

- Do you know how our mother met her end? Do you know what Houria was driven to by her love for a mountain, for that pure line of horison?

\begin{tabular}{|c|c|}
\hline & \\
\hline $\begin{array}{l}\text { Sais-tu, Petit Frère, comment a finit notre } \\
\text { mère? Sais-tu jusqu'où l'amour d'une } \\
\text { montagne, d'un horison a mené } \\
\text { Houria? } \\
\text { La montagne du lion, p. } 129\end{array}$ & $\begin{array}{l}\text { LITTLE BROTHER, do you know how our } \\
\text { mother met her end? Do you know what } \\
\text { Houria was driven to by her love for a } \\
\text { mountain, for that pure line of horison? } \\
\text { Lion mountain, p. } 112\end{array}$ \\
\hline
\end{tabular}

\section{DISCUSSION}

It must have been clear how making a judgment about the quality the above translation could not have been possible without first penetrating the personal, professional, cultural and linguistic worlds of the Mustapha Tlili. The assessment model adopted has a respect for the creativity a translator who manages to re-draw with local colors the beauties of the original text, as was successfully done with this novel. This means that a translator has a vision beyond the surface level of the text, beyond the word-for-word and free sense-for-sense dialectics. Di metaphorically explains that

The word-bound translator has his eyes fixed on the trees of words but fails to visualize the forest of imagery, while the verve-pursuing translator chooses some of the trees, those which appeal to his taste, and makes a new forest 
which pleases himself, whether it resembles the original or not. The messageoriented translator takes in the whole forest by observing its shape, its density, the way each tree grows and the part each one plays in the whole, and then on the basis of his empathetic and complete assimilation of the original forest, creates in the new soil a new forest which resembles the original as closely as possible. In order to do this, one will transplant all the trees that can acclimate to the new soil and replace those which cannot with new ones to make up for the loss. Both transplantation and replacement are performed for the purpose of giving new life to the original forest of artistic imagery in the new climate' (p.89).

What could also be considered an ethical side to this study is its call for resurrecting the 'forgotten' literary heritage of generations of Maghrebian authors that the new generations hardly know of. It is an attempt at a reconciliation between the Magrhrebian students and their culture, which seems to be increasingly losing ground in favor of emerging globalised cultural models

\section{CONCLUSION}

Assessment is a key issue in translation studies. It is perhaps what translation theory is all about. A multitude of translation quality assessment models have been devised, but none has ever managed to fulfill general applicability. The one proposed here is quite novel, and is more ethically and aesthetically convincing as far as doing justice to the individuality of the original author is concerned.

\section{REFERENCES}

BoaseBeier, J. (2010). Stylistic approaches to translation. London \& New York: Routledge.

Boudraa, N., \& García, S.K. (2014). Le Zèbre: A story by Mouloud Mammeri. International $\begin{array}{lllll}\text { Journal of } & \text { Francophone } & \text { Studies, } & \text { 107, }\end{array}$ http://www.intellectbooks.co.uk/journals/view-Journal,id=134/

Déjeux, J. (1992). La littérature Maghrébine d'expression française. Presses Universitaires de France.

Déjeux, J. (1988). Mustapha Tlili, La Montagne du lion. Hommes et Migrations, 1116, p. 43. Retrieved from http://www.persee.fr/doc/homig_1142852x_1988_num_1116_1_5684_t1_0043_0000_1

Di. J. (2003). Literary Translation: Quest for Artistic Integrity. London \& New York: Routledge.

Geniené, I. (2003). Language, literariness and pragmatics. Kalbotyra, 39 (2), 3-9.

Ghazala, H. S. (2018). The cognitive stylistic translator. AWEJ for translation \& literary studies, 2 (1), 4-25

Gontard, M. (1996). Mustapha Tlili. Retrieved from http://www.limag.refer.org/Textes/Manuref/Tlili.htm 
Khalid Majhad, Chakib Bnini \& Mohammed Kandoussi

Hatim, B., \& Munday, J. (2004). Translation: An advanced resource book. London \& New York: Routledge.

Herrmann, B. J., Dalen-Oskam, K., \& Schöch, Ch. (2015). Revisiting style: A key concept in literary studies. Journal of literary theory, 9(1), 25-52.

Jones, R.F. (2008). History. In M. Baker (Ed.). Routledge encyclopedia of translation studies. London \& New York: Routledge

Khadda, N. (1996). Mohammed Dib. Retrieved from http://limag.refer.org/Textes/Manuref/DIB.htm

Leech, G. N., \& Short, M. (2007). Style in Fiction (2nd ed.). Pearson Education Limited.

Munday, J. (2008). Introducing translation studies: Theories and applications. London \& New York: Routledge.

Nørgaard, N., Montoro, R., \& Busse, B. (2015). Key Terms in Stylistics. Continuum

Parks, T. (2007). Translating style: A literary approach to translation, a translation approach to literature. London \& New York: Routledge

Saldanha, G. \& O’Brien, S. (2013). Research methodologies in translation studies. London \& New York: Routledge.

Tlili, M. (1990). Lion mountain. (L. Coverdale, Trans.). Three Continents Press

Tlili, M. (1988). La montagne du lion. Gallimard

Toler, A. M. (2001). The Ethics of Cultural Representation: The Maghribi Novel in Translation. Journal of North African Studies, 6 (3), 48-69.

Wales, K. (1989). A Dictionary of Stylistics. Harlow: Longman 